\title{
Adobe Flash untuk Mendukung Pembelajaran dalam Pelajaran Seni Budaya
}

\author{
Mochamad Okky Candra P. \\ Pascasarjana Pendidikan Seni Budaya, Universitas Negeri Surabaya, \\ Jl. Lidah Wetan, Surabaya \\ Email: nyemnyemcheese@gmail.com
}

\begin{abstract}
Abstrak
Perkembangan Teknlogi yang kini membuat para pengajar harus meng-upgrade ilmu dan kreativitas dalam proses belajar mengajar, supaya pembelajaran tidak terasa menjemukan. Salah satunya belajar dengan menggunakan animasi komputer untuk memungkinkan siswa belajar secara dinamis dan lebih interaktif. Penggunaan media komputer sebagai media pembelajaran ini menghadirkan banyak manfaat, salah satu program yang mampu mendukung proses pembelajaran adalah program Adobe Flash. Adalah standar program aplikasi yang digunakan untuk membuat vektor animasi dan bitmap yang luar biasa untuk keperluan membuat situs Web yang interaktif dan dinamis. Aplikasi ini diimplementasikan sebagai media belajar. Pesan yang disampaikan melalui media, dalam bentuk konten atau bahan ajar itu harus diterima oleh siswa, dengan menggunakan satu atau kombinasi beberapa organ indera mereka. Bahkan lebih baik, ketika semua perangkat penginderaan yang dimiliki mampu menerima konten pesan yang disampaikan. Melalui makalah sebagai pustaka studi ini yang menggunakan SMP PGRI 5 Taman sebagai objek penelitian, dapat ditemukan bahwa kreativitas sangat diperlukan dalam hal pembelajaran, sedangkan animasi adalah alat dalam proses mengajar yang mampu menjadikan belajar menjadi lebih mudah dipahami oleh para siswa.
\end{abstract}

Kata kunci: Pengembangan, Media Pembelajaran, Adobe Flash.

\begin{abstract}
Technological developments now make teachers have to upgrade their knowledge and creativity in the teaching and learning process so that learning does not feel boring. One of them is learning by using computer animation to enable students to learn dynamically and more interactively. The use of computer media as a learning medium presents many benefits, one of the programs that can support the learning process is the Adobe Flash program. It is a standard application program used to create animated vectors and extraordinary bitmaps to create interactive and dynamic websites. This application is implemented as a learning medium. Messages conveyed through the media in the form of content or teaching materials must be received by students, using one or a combination of their sense organs. Even better, when all the sensing devices owned can receive the content of the message conveyed. Through this paper, as a literature study using SMP PGRI 5 Taman as the object of research, it can be found that creativity is very necessary for learning. While the animation is a tool in the teaching process that can make learning easier for students to understand.
\end{abstract}

Keywords: Development, Learning Media, Adobe Flash.

\section{Pendahuluan}

Dunia pendidikan saat ini telah mengalami perkembangan pesat seiring dengan perkembangan teknologi dan komunikasi. Masyarakat semakin menyadari akan pentingnya peran teknologi dan komunikasi dalam menunjang terlaksananya pendidikan yang sesuai dengan era globalisasi. Dunia pendidikan saat ini sedang berlomba-lomba untuk mengembangkan kemampuan dibidang teknologi dan komunikasi, berkembang dari abad ke abad pendidikan semakin maju tanpa meninggalkan sistem-sistem yang awal dahulu digunakan. Peningkatan inovasi dalam pembelajaran harus terus dilakukan baik itu berupa metode mengajar dan media pembelajaran sebagaimana dua unsur tersebut harus diperhatikan. Sebagaimana telah dikemukakan oleh Arsyad (2015:19), dalam proses belajar mengajar dua unsur yang sangat penting di antaranya metode pembelajaran dan media pembelajaran. Kedua aspek ini saling berkaitan sebagaimana pemilihan jenis media pembelajaran yang baik diharapkan mampu menunjang keberhasilan proses pembelajaran.

Menurut Suyono \& Hariyanto (2015:19), metode pembelajaran adalah seluruh perencanaan dan prosedur maupun langkah-langkah kegiatan 
pembelajaran termasuk pilihan cara penilaian yang akan dilaksanakan. Sedangkan Munadi (2013:8) mengemukakan bahwa media pembelajaran adalah segala sesuatu yang dapat menyampaikan dan menyalurkan pesan dari sumber secara terencana sehingga tercipta lingkungan belajar yang kondusif di mana penerimanya dapat melakukan proses belajar secara efisien dan efektif. Media pembelajaran dapat dikelompokkan ke dalam empat kelompok besar yaitu: media audio, media visual, media audio-visual, dan multimedia, salah satu fungsi media pembelajaran adalah sebagai alat bantu mengajar yang turut mempengaruhi iklim, kondisi, dan lingkungan belajar yang ditata dan diciptakan oleh guru.

Dalam Kamus Besar Bahasa Indonesia (2008:892) yang mengatakan, bahwa: "Media adalah alat (sarana) komunikasi seperti koran, majalah, radio, televisi, film, poster, dan spanduk". Dari pendapat diatas dapat disimpulkan bahwa media pembelajaran adalah semua benda perlengkapan yang digunakan untuk memberikan materi dengan cara yang menarik dan juga mampu menambah kreatifitas melalui sarana yang telah diberikan. Sedangkan menurut Harjanto (2008:243) beberapa manfaat media pembelajaran antara lain:

a. Bahan pengajaran akan lebih jelas maknanya sehingga menguasai tujuan pangajaran yang lebih baik.

b. Metode pengajaran akan lebih bervariasi, tidak semata-mata komunikasi verbal melalui penuturan kata-kata sehingga tidak bosan dan tidak kehabisan tenaga, apalagi bila mengajar pada setiap jam pelajaran.

c. Lebih banyak melakukan kegiatan belajar, sebab tidak hanya mendengarkan uraian, tetapi juga aktifitas lain seperti mengamati, melakukan, mendengar, mendemonstrasikan, dan lain-lain.

d. Pengajaran akan lebih menarik perhatian sehingga dapat menumbuhkan motivasi belajar. Ada beberapa macam penggolongan media pembelajaran, mulai dari yang sederhana sampai yang canggih.

Sistematika pengategorian media pembelajaran menurut Winkel (2001:287), yaitu:

a. Media visual yang tidak menggunakan proyeksi, misalnya papan tulis, buku pelajaran, papan yang dapat ditempeli gambaran dan tulisan (display board), lembaran kertas besar yang diganti-ganti (flipcharts), klipping dari surat kabar dan majalah, poster, dan model berskala besar atau kecil.

b. Media visual yang menggunakan proyeksi, seperti film, kaset video, proyektor untuk kertas transparan plastik, proyektor untuk memantulkan halaman dalam buku pada sebuah layar dan siaran televisi pendidikan. c. Media auditif, seperti gramofon, kaset yang berisikan ceramah atau wawancara dengan seseorang, kaset ucapan bahasa asing, kaset musik dan siaran radio.

d. Media kombinasi visual-auditif yang diciptakan sendiri seperti serangkaian slide dikombinasikan dengan kaset audio; atau diproduksikan oleh perusahaan seperti disket video, dan program komputer yang dapat berbicara.

Dari pendapat diatas disimpulkan bahwa media bisa digunakan dengan cara yang praktis dan canggih yang dapat membantu dalam meningkatkan kecermatannya dalam pembelajaran yang akan diberikan oleh guru, pemanfaatan media tersebut dapat membantu daya pikir menjadi bertambah dan membantu kegiatan praktek yang akan dihadapinya.

\section{Pengertian Adobe Flash}

Perangkat lunak Adobe Flash yang selanjutnya disebut Flash, dulunya bernama "Macromedia Flash". Flash merupakan salah satu jenis program animasi vector yang dikembangkan oleh perusahaan Macromedia Inc., untuk digunakan pada halaman Web, sehingga dapat ditampilkan di Internet dengan bantuan plugin tertentu. Sejak diperkenalkan pada tahun 1996, Flash atau Macromedia Flash menjadi sangat populer dan langsung mendapat tempat di hati masyarakat dunia Web karena dapat membuat menampilkan animasi dan interaksi di Web. Tetapi sejak bulan Desember 2005, perusahaan Macromedia dibeli oleh Adobe dan kini berganti nama menjadi Adobe Flash. Aplikasi ini terus dikembangkan menjadi Adobe Flash CS 4 dan versi terbarunya adalah Adobe Flash C5. "Flash merupakan software multimedia unggulan. Sejak tahun 1996 Flash menjadi metode populer untuk menambahkan animasi dan interaktif Website. Flash biasanya digunakan untuk membuat animasi, hiburan dan berbagai komponen $W e b$, diintegrasikan dengan video dalam halaman $W e b$ sehingga dapat menjadi aplikasi multimedia yang kaya (rich aplication).

Menurut Zainul Fanani (2006:2) mengatakan, bahwa Flash tidak hanya digunakan untuk aplikasi Web, tetapi juga dapat dikembangkan untuk membangun aplikasi dekstop . Kemampuan Flash dalam menciptakan beragam animasi yang menghiasi Website selama ini memang sudah tidak dapat dipungkiri lagi. Bahkan banyak Web developer yang membangun situsnya mempergunakan kemampuan animasi Flash ini. Adobe Flash adalah sebuah program animasi yang telah banyak digunakan oleh para desainer untuk menghasilkan desain yang profesional. 
Salah satu hal yang menjadikan Adobe Flash merupakan program animasi populer adalah kemudahan pengoperasian dengan hasil lebih maksimal dari yang diperkirakan penggunanya. Animasi bisa didefenisikan sebagai proses perubahan bentuk atau properti obyek yang ditampilkan dalam suatu gerakan transisi dalam suatu kurun waktu. Kelebihan dan kemampuan Adobe Flash, yaitu:

a. Merupakan teknologi animasi Web yang paling populer saat ini sehingga banyak didukung oleh berbagai pihak.

b. Ukuran file yang kecil dengan kualitas yang baik.

c. Kebutuhan hardware yang tidak tinggi.

d. Dapat membuat Website, CD interaktif, animasi Web, animasi kartun, kartu elektronik, iklan TV, banner di Web, presentasi, membuat permainan (game), aplikasi Web dan handphone.

e. Dapat ditampilkan di banyak media seperti Web, CD-ROM, VCD, DVD, televisi, handphone, dan PDA.

Perkembangan teknologi di dunia pendidikan dan pembelajaran belum sepenuhnya bisa dimanfaatkan secara maksimal oleh guru, banyak guru yang masih menggunakan metode mengajar ceramah. Metode ceramah ini merupakan metode penyampaian materi dari guru kepada siswa dengan cara guru menyampaikan materi melalui bahasa lisan baik verbal maupun nonverbal, dalam hal ini kedudukan siswa adalah sebagai penerima materi pembelajaran dan guru sebagai sumber belajar. Metode ini menuntut keaktifan guru sehingga guru dituntut untuk menyampaikan materi yang mudah dipahami siswa terkadang juga dengan metode ini terlihat monoton, sehingga siswa merasa bosan. Oleh karena itu, guru harus memiliki kemampuan dan keterampilan menggunakan metode pembelajaran lain.

Namun, metode pembelajaran ceramah tersebut tidak serta merta ditinggalkan, akan tetapi guru harus menggunakan kombinasi metode pembelajaran ceramah dengan metode pembelajaran lain pada setiap pertemuan. Penggunaan metode pembelajaran ceramah biasanya efektif digunakan pada proses awal pembelajaran dilakukan atau ketika guru memberikan pengantar kepada peserta didik sebelum mengkombinasikan dengan metode pembelajaran lain yang akan digunakan. Dalam pembelajaran Seni budaya (Seni Rupa) kelas VII di SMP PGRI 5 Taman ditandai dengan ceramah dan dilanjutkan dengan penjelasan, kemudian dilanjutkan dengan praktik membuat karya.

Berdasarkan pengamatan peneliti pada saat pembelajaran seni budaya, penyampaian materi oleh guru kebanyakan hanya mengunakan metode ceramah, guru hanya menggunakan media papan tulis, dan alat peraga untuk mencatat sambil menerangkan materi pelajaran ragam hias. Untuk penggunaan media pembelajaran sudah ada media digital untuk membantu memberikan materi pelajaran, yaitu PowerPoint, tetapi belum maksimal. Penggunaan media dapat membantu siswa lebih memahami materi dan dapat mengulang isi materi ketika diperlukan. Selain itu, dalam proses pembelajaran situasi belajar kurang kondusif, respon peserta didik kurang terlihat dalam proses pembelajaran cenderung kurang komunikatif dan tidak efektif baik dalam proses pembelajaran teori maupun praktik.

Oleh karena itu, berdasarkan uraian latar belakang permasalahan diatas, keberadaan media pembelajaran interaktif sangat membantu untuk mengatasi permasalahan tersebut dan juga mempermudah dalam menyampaikan pesan- pesan dari bahan pembelajaran yang akan disampaikan oleh guru kepada peserta didik. Sebagaimana Munadi (2013:152), mengemukakan bahwa beberapa hal media pembelajaran dapat menggantikan fungsi guru terutama sebagai sumber belajar, salah satu media yang dapat menjalankan fungsi demikian tersebut adalah multimedia interaktif. Media pembelajaran interaktif diprogram atau dirancang untuk dipakai oleh siswa secara individual (belajar mandiri), selain dari pada itu media pembelajaran interaktif dapat digunakan dalam kegiatan pembelajaran, sebab cukup efektif meningkatkan hasil belajar peserta didik dan penggunaanya cocok untuk mengajarkan suatu proses atau tahapan. Dengan demikian terdapat berbagai macam teknologi multimedia untuk membuat media pembelajaran interaktif yaitu dengan Adobe Flash.

Adobe Flash merupakan salah satu software animasi yang sangat populer dan sudah diakui kecanggihannya, kelengkapan fasilitas dan kemampuan yang luar biasa dalam membuat animasi menjadikan software ini banyak dipakai oleh animator flash, karena keberadaanya benarbenar mampu membantu dan memudahkan pemakai dalam menyelesaikan pekerjaan, terutama pekerjaan animasi dan presentasi. Media pembelajaran interaktif menggunakan aplikasi Adobe Flash ini hanyalah sebagai alat bantu menyalurkan ilmu materi pembelajaran ragam hias dari guru ke peserta didik. Dengan demikian dengan menggunakan bantuan media pembelajaran interaktif ini diharapkan dapat menambah respon siswa dalam mengikuti proses pembelajaran serta membuat situasi belajar yang kondusif dan menarik untuk peserta didik, selain itu diharapkan 
dapat membuat semangat belajar siswa agar peserta didik terus meningkatkan prestasi belajarnya.

\section{Komputer sebagai Alat Bantu Pembelajaran}

Banyak keuntungan diperoleh dari penggunaan media komputer sebagai alat bantu pembelajaran. Beberapa ahli menyatakan bahwa pengajaran yang menggunakan komputer dapat mengembangkan keterampilan berpikir. Selain itu penggunaan media komputer dapat menyeimbangkan kebutuhan waktu dan keperluan pemrosesan dari tugas-tugas tertentu, serta memungkinkan pengembangan pendekatan pembelajaran bervariasi. Komputer (mikro) dapat merupakan media pengajaran yang dapat mem-visualisasikan berbagai fakta, keterampilan, konsep dan komputer juga menampilkan gambar-gambar yang bergerak sesuai dengan keperluannya. Penggunaan komputer yang bersifat interaktif dengan pemakainya bahwa program komputer yang dapat menampilkan diagram atau gambar dapat dirancang ntuk menyesuaikan dengan respon pembelajar.

Selain itu, penggunaan komputer dapat dirancang sedemikian sehingga dapat berinteraksi dengan pemakainya. Komputer selain dapat menciptakan iklim belajar yang efektif bagi siswa yang lambat (slow learner), tetapi juga dapat memacu efektivitas belajar bagi siswa dan siswi yang lebih cepat (fast learner). Sejalan dengan pendapat yang dikemukakan Heinich, kenyataan di lapangan memperlihatkan bahwa kecepatan pembelajar mempelajari suatu ma-teri tidak hanya ditunjang oleh kemampuan kognisi pembelajar tetapi juga dipengaruhi oleh kemampuan siswa dan siswi dalam mengoperasikan komputer. Ada beberapa kelemahan penggunaan komputer seba-gai media pembelajaran. Tidak semua komputer dapat digunakan sebagai media pembelajaran, komputer harus menunjukkan kinerja yang baik ditinjau dari segi teknis dan spesifikasinya.

Belajar dengan menggunakan media komputer menjadikan siswa aktif dalam belajar karena adanya pertanyaan-pertanyaan yang disertai dengan pernyataan penguatan. Motivasi siswa dan siswi bertambah karena mereka lebih mudah mengikuti dan memahami materi yang diberikan. Beberapa kelebihan komputer antara lain :

1. Bekerja dengan komputer sebagai sesuatu yang baru bagi siswa dan siswi, menimbulkan motivasi bagi mereka untuk lebih menekuni materi yang disajikan.

2. Dengan adanya warna, musik, dan grafik yang dianimasi dapat menambahkan realisme, dan merangsang untuk mengadakan latihanlatihan kerja, kegiatan laboratorium, simulasi dan sebagainya.
3. Kecepatannya dalam hal menanggapi respon, justru merupakan sesuatu yang mengandung nilai-nilai penguatan (reinforcement).

4. Kemampuannya untuk mengingat secara cepat dan tepat, memungkinkan perlakuan/pekerjaan yang lalu dapat dicatat dengan baik, dan dapat digunakan untuk merencanakan langkah-langkah selanjutnya.

Andai kata komputer itu manusia, maka dapat digambarkan sebagai suatu pribadi yang sabar, sehinga dalam hal menggunakannya nampak suatu suasana tenang, aman, positif, dan tepat guna. Kemampuan komputer dalam hal menyimpan dokumen secara aman, memungkinkan pengajaran individual dapat dijalankan dengan baik. Bagi pendidik, persiapan-persiapan dapat dijalankan dengan baik untuk semua siswa/ wi dan kemajuan mereka dapat dimonitor.

\section{Media Pembelajaran}

Kata "media" berasal dari bahasa latin yang merupakan bentuk jamak dari kata "medium" yang secara harfiah yaitu "perantara" atau pengantar pesan dari pengirim pesan kepada penerima pesan (Azha r Arsyad, 2010: 6). Menurut Oemar Hamalik (2010: 201) "media adalah suatu eksistensi manusia yang memungkinkan mempengaruhi orang lain yang tidak mengadakan kontak langsung dengan dia. Sedangkan definisi media pembelajaran menurut John D. Latuheru yang dikutip oleh Santoso S. Hamidjojo (1998: 16) yaitu "media adalah semua bentuk perantara yang digunakan oleh manusia untuk menyampaikan atau menyebar ide, sehingga ide, atau pendapat, atau gagasan yang dikemukakan atau disampaikan itu bisa sampai pada penerima". Pendapat lain yang dikemukakan oleh Sudjana dan Rivai (2010: 1) "media pengajaran adalah alat bantu mengajar yang ada dalam komponen metodologi pengajaran, sebagai salah satu lingkungan belajar yang diatur oleh guru". Dari teori-teori di atas dapat diambil kesimpulan bahwa media pembelajaran adalah suatu alat, bahan ataupun berbagai macam komponen yang digunakan dalam kegiatan belajar mengajar dari pengajar (guru) kepada pembelajar (siswa) agar dapat memudahkan pembelajar dalam menerima suatu materi.

\section{Fungsi Media Pembelajaran}

Rusman (2009:154) mengungkapkan peranan media dalam proses pembelajaran dapat ditempatkan sebagai berikut: Sebagai alat untuk memperjelas bahan pembelajaran pada saat guru menyampaikan pelajaran. Dalam hal ini media digunakan guru sebagai variasi penjelasan verbal mengenai bahan pembelajaran Alat untuk mengangkat atau menimbulkan persoalan untuk dikaji 
lebih lanjut oleh para siswa dalam proses belajarnya. Paling tidak guru dapat menempatkan media sebagai sumber pertanyaan atau stimulus belajar siswa sumber belajar bagi siswa, artinya media tersebut berisikan bahan-bahan yang harus dipelajarai para siswa baik secara individual maupun kelompok. Dengan demikian akan banyak membantu tugas guru dalam kegiatan mengajar. Fungsi media pembelajaran menurut Levie dan Lentz dalam Azhar Arsyad (2010: 16), yaitu:

a. Fungsi atensi yaitu menarik dan mengarahkan perhatian siswa untuk berkonsentrasi kepada isi pelajaran yang berkaitan dengan makna visual yang ditampilkan atau menyertai teks materi pelajaran atau pelajaran itu merupakan salah satu pelajaran yang tidak disenangi oleh mereka sehingga mereka tidak memperhatikan.

b. Fungsi afektif dapat terlihat dari kenikmatan siswa ketika belajar (membaca) teks yang bergambar.

c. Fungsi kognitif terlihat dari temuan-temuan penelitian yang mengungkapkan bahwa lambang visual memperlancar pencapaian tujuan untuk memahami dan mengingat informasi atau pesan yang terkandung dalam gambar.

d. Fungsi kompensatoris terlihat dari hasil penelitian bahwa media visual yang membantu siswa yang lemah dalam membaca untuk mengorganisasikan informasi dalam teks dan mengingatnya kembali. Berdasarkan atas beberapa fungsi media pembelajaran yang dikemukakan di atas, maka dapat disimpulkan bahwa penggunaan media dalam kegiatan belajar mengajar memiliki pengaruh yang besar terhadap alat-alat indera. Terhadap pemahaman isi pelajaran, secara nalar dapat dikemukakan bahwa dengan penggunaan media akan lebih menjamin terjadinya pemahaman yang lebih baik pada siswa. Siswa yang belajar lewat mendengarkan saja akan berbeda tingkat pemahaman dan lamanya "ingatan" bertahan, dibandingkan dengan siswa yang belajar lewat melihat atau sekaligus mendengarkan dan melihat. Media pembelajaran juga mampu membangkitkan dan membawa siswa ke dalam suasana rasa senang dan gembira, di mana ada keterlibatan emosianal dan mental. Tentu hal ini berpengaruh terhadap semangat mereka belajar dan kondisi pembelajaran yang lebih hidup, yang nantinya bermuara kepada peningkatan pemahaman siswa terhadap materi ajar.

\section{Macam-macam Media Pembelajaran}

Media pembelajaran menurut Syaiful Bahri Djamarah (2006: 124) dibagi menjadi tiga macam, yaitu: a) Dilihat dari jenisnya:

1. Media Auditif, adalah media yang hanya mengandalkan kemampuan suara saja, seperti radio, cassete recorder, piringan hitam.

2. Media Visual, adalah media yang hanya mengandalkan indra penglihatan.

3. Media Audiovisual, adalah media yang mempunyai unsur suara dan unsur gambar.

b) Dilihat dari daya liputanya, media dibagi dalam:

1. Media dengan gaya liput luas dan serentak Penggunaan media ini tidak terbatas oleh tempat dnan ruang serta dapat menjangkau jumlah anak didik yang banyak dalam waktu yang sama. Contoh : radio dan televisi.

2. Media dengan daya liput yang terbatas oleh ruang dan tempat Media ini dalam penggunaanya membutuhkan ruang dan tempat yang khusus seperti film, sound slide, film rangkai, yang harus menggunakan tepat yang tertutup dan gelap.

3. Media untuk pengajaran individual Media ini penggunaannya hanya untuk seorang diri. Termasuk media ini adalah modul berprogram dan pengajaran melalui komputer.

c) Dilihat dari bahan pembuatanya

1. Media sederhana. Media ini bahan dasarnya mudah diperoleh dan harganya murah, cara pembuatanya mudah, peggunaannya tidak sulit.

2. Media kompleks. Media ini adalah media yang bahan dan alat pembuatan dan penggunaanya memerlukan keterampilan yang memadai. Prestasi belajar siswa dipengaruhi oleh beberapa macam media pembelajaran.

Terkait dalam penelitian ini, penggunaan media pembelajaran yang paling berpengaruh terhadap prestasi belajar menggunakan peralatan kantor adalah dari daya liputannya yaitu media untuk pengajaran individual. Media ini penggunaaanya hanya untuk individual, tujuan dari media ini adalah untuk melatih kecakapan dan ketrampilan. Siswa akan lebih mudah memahami manfaat dan kegunaan alat-alat kantor jika siswa dapat mengoperasikan alat-alat kantor langsung.

\section{Klasifikasi Macam-Macam Media Pem- belajaran}

1. Media Audio

Media audio berfungsi untuk menyalurkan pesan audio dari sumber pesan ke penerima pesan. Media audio berkaitan erat dengan indra pendengaran.contoh media yang dapat dikelompokkan dalam media audio diantaranya: radio, tape recorder, telepon, laboratorium bahasa, dll. 
2. Media Visual

Media visual yaitu media yang mengandalkan indra penglihat. Media visual dibedakan menjadi dua yaitu (1) media visual diam (2) media visual gerak:

a. Media visual diam contohnya foto, ilustrasi, flashcard, gambar pilihan dan potongan gambar, film bingkai, film rngkai,OHP, grafik, bagan, diagram, poster, peta, dan lainlain.

b. Media visual gerak contohnya gambargambar proyeksi bergerak seperti film bisu dan sebagainya.

3. Media audio visual

Media audiovisual merupakan media yang mampu menampilkan suara dan gambar. Ditinjau dari karakteristiknya media audio visual dibedakan menjadi dua yaitu (1) madia audio visual diam, dan (2) media audio visual gerak.

a). Media audiovisual diam diantaranya TV diam, film rangkai bersuara, halaman bersuara, buku bersuara.

b). Media audio visual gerak diantaranya film TV, TV, film bersuara, gambar bersuara, dll.

4. Media Serbaneka

Media serbaneka merupakan suatu media yang disesuaikan dengan potensi di suatu daerah, di sekitar sekolah atau di lokasi lain atau di masyarakat yang dapat dimanfaatkan sebagai media pengajaran. Contoh media serbaneka diantaranya: Papan tulis, media tiga dimensi, realita, dan sumber belajar pada masyarakat.

a). Papan (board) yang termasuk dalam media ini diantaranya : papan tulis, papan buletin, papan flanel, papan magnetik, papan listrik, dan papan paku.

b). Media tiga dimensi diantaranya: model, mock up, dan diorama.

c). Realita adalah benda-benda nyata seperti apa adanya atau aslinya, contoh pemanfaatan realit misalnya guru membawa kelinci, burung, ikan atau dengan mengajak siswanya langsung ke kebun sekolah atau ke peternakan sekolah.

d). Sumber belajar pada masyarakat diantaranya dengan karya wisata dan berkemah

Latuheru (1988) menyatakan bahwa (1) media pembelajaran berguna menarik minat siswa terhadap materi pembelajaran yang disajikan, (2) media pembelajaran berguna dalam hal meningkatkan pengertian anak didik terhadap materi yang disajikan, (3) media pembelajaran mampu menyajikan data yang kuat dan terpercaya.

Heinich, Malenda, Russel (1982) dalam Ilda Prayitno (1989) mengemukakan keuntungan penggunaan media dalam pembelajaran adalah:
1. Membangkitakan ide-ide atau gagasan-gagasan yang bersifat konseptual, sehingga mengurangi kesalahpahaman siswa dalam mempelajarinya.

2. Meningkatkan minat siswa untuk materi pelajaran.

3. Memberikan pengalaman-pengalaman nyata yang merangsang aktivitas diri sendiri untuk belajar.

4. Dapat mengembangkan jalan pikiran yang berkelanjutan.

5. Menyediakan pengalaman-pengalaman yang tidak mudah didapat melalui materi-materi yang lain dan menjadikan proses belajar mendalam dan beragam. Sehingga pembuatan media pembelajaran diperlukan untuk proses pelaksanaan pembelajaran dan proses berpikir siswa.

\section{Manfaat positif dari penggunaan media}

Sebagai bagian integral pengajaran di kelas adalah sebagai berikut:

1. Penyampaian pelajaran menjadi lebih baku. Setiap pelajar yang melihat atau mendengar penyajian melalui media menerima pesan yang sama.

2. Pengajaran bisa lebih menarik. Media dapat diasosiasikan sebagai penarik perhatian dan membuat siswa tetap terjaga dan memperhatikan.

3. Pembelajaran menjadi lebih interaktif dengan diterapkannya teori belajar dan prinsip-prinsip psikologis yang diterima dalam hal partisipasi siswa, umpan balik, dan penguatan.

4. Lama waktu pengajaran yang diperlukan dapat dipersingkat untuk mengantarkan pesanpesan dan isi pelajaran dalam jumlah yang cukup banyak dan kemungkinannya dapat diserap oleh siswa.

5. Kualitas hasil belajar dapat ditingkatkan

6. Pengajaran dapat diberikan kapan dan dimana diinginkan.

7. Sikap positif siswa terhadap apa yang mereka pelajari dan terhadap proses belajar dapat ditingkatkan.

8. Peran guru dapat berubah kearah yang lebih positif,dalam proses belajar mengajar.

\section{Manfaat Media Pembelajaran}

Peran media dalam pembelajaran sangatlah penting terutama bagi siswa. Minat dan motivasi belajar siswa dapat ditumbuhkan dengan menggunakan media pembelajaran yang menarik. Proses belajar yang membosankan di dalam kelas juga dapat dihilangkan dengan menggunakan 
media yang menyenangkan bagi siswa. Manfaat media yang terpenting adalah sebagai saluran untuk menyampaikan informasi atau materi pembelajaran secara verbalistis (ceramah) serta merangsang perhatian dan mengaktifkan siswa. Penyampaian materi secara verbalistis dapat membuat siswa cepat bosan, hal ini dikarenakan guru dalam menyampaikan setiap topik secara monoton. Selain itu membuat siswa cenderung pasif, interaksi guru dan siswa hanya dilakukan satu arah.

Kemp dan Dayton (Azhar Arsyad, 2010:21) mengemukakan dampak positif dari penggunaan media pembelajaran, yaitu penyampaian pelajaran menjadi lebih baku, pembelajaran bisa lebih menarik, pembelajaran menjadi lebih interaktif, lama waktu pembelajaran yang diperlukan dapat dipersingkat, kualitas hasil belajar meningkat, pembelajaran dapat diberikan kapan dan dimana saja, sikap positif siswa terhadap apa yang mereka pelajari dan proses belajar dapat ditingkatkan, peran guru dapat berubah ke arah yang lebih positif. Manfaat dari penggunaan media pembelajaran akan dapat dirasakan secara optimal apabila guru mampu memilih dan menggunakan media tersebut sesuai dengan tujuan dan fungsinya .

Berbagai manfaat media pembelajaran telah dibahas oleh banyak ahli, seperti Sudjana dan Rivai (2010:2) mengemukakan manfaat media pembelajaran dalam proses belajar mengajar siswa, yaitu:

a) Pembelajaran akan lebih menarik perhatian siswa sehingga dapat menimbulkan motivasi belajar siswa.

b) Bahan pembelajaran akan lebih jelas maknanya sehingga lebih dipahami.

c) Metode mengajar akan lebih bervariasi, tidak semata mata komunikasi verbal melalui penuturan kata-kata oleh guru, sehingga tidak merasa bosan.

d) Siswa lebih banyak melakukan kegiatan belajar sebab tidak hanya mendengarkan uraian guru, tetapi juga aktivitas lain seperti mengamati, melakukan, mendemonstrasikan dan lain-lain.

e) Dari beberapa teori di atas dapat disimpulkan bahwa manfaat dari media pembelajaran di antaranya yaitu, dapat membantu mempermudah pengajar dalam menyampaikan materi, dapat membuat pembelajaran lebih menarik dan bervariasi, siswa tidak akan merasa bosan atau jenuh, dapat menumbuhkan motivasi belajar siswa dan meningkatkan prestasi belajar.

\section{Aplikasi Adobe Flash}

Adobe Flash adalah aplikasi yang dipakai luas oleh para profesional Web karena kemampuannya yang mengagumkan dalam menampilkan multimedia, menggabungkan unsur teks, grafis, animasi, suara dan serta interaktivitas bagi pengguna program animasi internet. Dewasa ini Adobe Flash telah men-jadi primadona para designer Web sebagai sarana untuk menciptakan sebuah situs Web yang menarik dan interaktif. Adobe Flash (Flash MX) merupakan sebuah program aplikasi standar authoring tool profesional yang digunakan untuk membuat animasi vektor dan bitmap yang sangat menakjubkan untuk keperluan pembuatan situs Web yang interaktif dan dinamis. Selain itu, aplikasi ini juga dapat diguna-kan untuk membuat animasi logo, film, permainan, pembuatan navigasi pada situs Web, banner, tombol animasi, menu interaktif, interaktif form isian, e-card, screen saver dan pembuatan keseluruhan isi Web atau pembuatan aplikasi-aplikasi Web lain.

\section{Pembahasan}

Animasi dan gambar yang dibuat dengan Flash akan tetap terlihat bagus pada ukuran Windows dan resolusi layar berapapun. Hal ini disebabkan karena Flash dibuat dengan teknologi vector graphic yang mendeskripsikan gambar memakai garis dan kurva, sehingga ukurannya dapat diubah sesuai kebutuhan tanpa mengurangi atau mempengaruhi kualitas dari gambar tersebut. Waktu loading (dengan pengolahan animasi lainnya, animasi lainnya, seperti animated gifs dan java ap plet. Juga mampu membuat Website yang interaktif, karena user dapat menggunakan keyboard atau tetikus untuk berpindah ke bagian lain dari halaman Web atau movie, memindahkan objek, memasukkan informasi di form. Mampu menganimasi grafis yang rumit dengan sangat cepat, sehingga membuat animasi layar penuh bisa langsung disambung ke situs Web. Dapat diintegrasikan dengan server side scripting seperti CGI, ASP dan PHP untuk membuat aplikasi Web database yang indah. Selain itu, dapat juga dipakai untuk membuat film pendek atau kartun, presentasi, iklan atau Web banner, animasi logo, kontrol navigasi dan lain-lain. Flash $M X$ juga menyediakan kemampuan streaming video yang baru yang telah dikembangkan ke berbagai format video termasuk format MPG, DV (Digital Video), MOV (Quick time) dan AVI. Format-format video tersebut dapat disimpan ke dalam file Flash $M X$ menggunakan kompresi file yang lebih baik. Dukungan video yang lebih luas tersebut memungkinkan kreativitas yang lebih baik dalam membuat movie flash. Kelebihan-kelebihan Adobe Flash $M X$ 
dapat dimanfaatkan dalam dunia pendidikan guna tercapainya tujuan pembelajaran. Kelebihan ini telah digunakan dalam merancang program pembelajaran berbasis komputer seperti kemampuannya menggabungkan kemampuan animasi huruf dan gambar yang menarik, animasi gambar dan huruf tetap terlihat bagus pada ukuran Windows dan resolusi layar berapapun,' kecepatan gambar, animasi atau huruf yang akan ditampilkan (muncul) dapat diatur kecepatannya serta dilengkapi dengan fasilitas tombol untuk dapat berpindah dari satu bagian ke bagian lainnya. Aplikas iyang dikembangkan adalah media aplikasi yang interaktif. Untuk menguji tingkat interaktifitas model, akan dikembangkan: Instrumen berupa kuesioner masing-masing untuk pendidik, dan siswa, dan frekuensi akses siswa. Aplikasi yang dikembangkan adalah sarana belajar yang bertujuan untuk meningkatkan transfer informasi.

\section{Simpulan}

Banyak keuntungan diperoleh dari penggunaan media komputer sebagai alat bantu pembelajaran. Beberapa ahli menyatakan bahwa pengajaran yang menggunakan komputer dapat mengembangkan keterampilan berpikir. Selain itu penggunaan media komputer dapat menyeimbangkan kebutuhan waktu dan keperluan pemrosesan dari tugastugas tertentu, serta memungkinkan pengembangan pendekatan pembelajaran bervariasi. media pengajaran adalah alat bantu mengajar yang ada dalam komponen metodologi pengajaran, sebagai salah satu lingkungan belajar yang diatur oleh guru. Dari teori-teori di atas dapat diambil simpulan bahwa media pembelajaran adalah suatu alat, bahan ataupun berbagai macam komponen yang digunakan dalam kegiatan belajar mengajar dari pengajar (guru) kepada pembelajar (siswa) agar dapat memudahkan pembelajar dalam menerima suatu materi. Animasi dan gambar yang dibuat dengan Flash akan tetap terlihat bagus pada ukuran windows dan resolusi layar berapapun.
Hal ini disebabkan karena Flash dibuat dengan teknologi vector graphic yang mendeskripsikan gambar memakai garis dan kurva, sehingga ukurannya dapat diubah sesuai kebutuhan tanpa mengurangi atau mempengaruhi kualitas dari gambar tersebut. Waktu loading (dengan pengolahan animasi lainnya, animasi lainnya, seperti animated gifs dan java ap plet. Juga mampu membuat Website yang interaktif, karena user dapat menggunakan keyboard atau tetikus untuk berpindah ke bagian lain dari halaman Web atau movie, memindahkan objek, memasukkan informasi di form. Mampu menganimasi grafis yang rumit dengan sangat cepat, sehingga membuat animasi layar penuh bisa langsung disambung ke situs Web. Dapat diintegrasikan dengan server side scripting seperti CGI, ASP dan PHP untuk membuat aplikasi Web database yang indah. Selain itu, dapat juga dipakai untuk membuat film pendek atau kartun, presentasi, iklan atau Web banner, animasi logo, kontrol navigasi dan lain-lain.

\section{Daftar Pustaka}

Arsyad, Azhar. (2015). Media Pembelajaran. Jakarta: Raja Grafmdo Persada.

Munadi, Yudhi. (2013). Media Pembelajaran (Sebuah Pendekatan Baru). Jakarta: Referensi (GP Press Group).

Suyono \& Hariyanto. 2015. Belajar dan pembelajaran. Bandung: PT. Remaja Rosdakarya.

Pardosi, Mico. (2007). Pengantar Instalasi Jaringan, Bandung: Penerbit Informatika.

Reksowardojo, Bambang P., Djalle, Zaharuddin G. (2005). Kreativitas Visual dengan 3Ds MAX. Bandung: Informatika.

Sopandi, Dede. (2006). Instalasi dan Konfigurasi Jaringan Komputer. Bandung: Penerbit Informatika.

Fanani, Zainul. (2006). Tip dan Trik Animasi Macromedia Flash. Yogyakarta: Graha Ilmu.

Hamalik. (2009). Kurikulum dan Pembelajaran. Jakarta: Bumi Aksara 